\title{
AN ATTEMPT ON NEUTRALIZE ACIDIFIED : MOUNTAIN WATERS ON E XAMPE OF THE INVESTIGATED STREAMS: THE CZERWIEŃ, MYJA AND PODGÓRNA
}

\author{
PRÓBA NEUTRALIZACJ ZAKWASZONYCH WÓD GÓRSTCH \\ NA PRZYKCADZIE BADANYCH POTOKÓW: CZERWIEŃ, MYJA I PODGÓRNA
}

\author{
Univerity of Stroedin
}

In the course of the research (hydrobiological and hydrochemical) on the three mountain streams was found out that acidification was a main agent which disqualified a quality of their water. An attempt on neutralize of water of the Czerwien stream was undertaken by means of "cushions" (with chalk and without chalk) - an enclaves of the neutralized environment and with the use of model mechanism as well.

The advantageous impact of the neutralized water on macrobenthos and fishes was found out and confirmed by means of numerous biological test.

\section{INTRODUCTION}

Nowadays, development of degradation of the environment went so far that water or rather its scarcity become an obstacle not only to industry development but also to normal operation of many branches of economy. Thus there is important an ecological point of view on these affairs. It means that water should be recognized as circulative within ecosystem the article of first necessity. People who believe that all troubles with water, for example supply with water, can be overcome by the building of dams or others technical installations they show a knowledge about an achievements in engineering but their ecological knowledge should be deepened.

"Clean water" is necessary for all living organisms because it plays a part of limiting agent in ecosystems, not only for man. Quality of water must be controlled and evaluated for two fundamental reasons: firstly, for assessment of effectiveness of the water pollution control, secondly, for evaluation of the usefulnesses of water (for example: river as source of the water supply for industry, agriculture or population). 


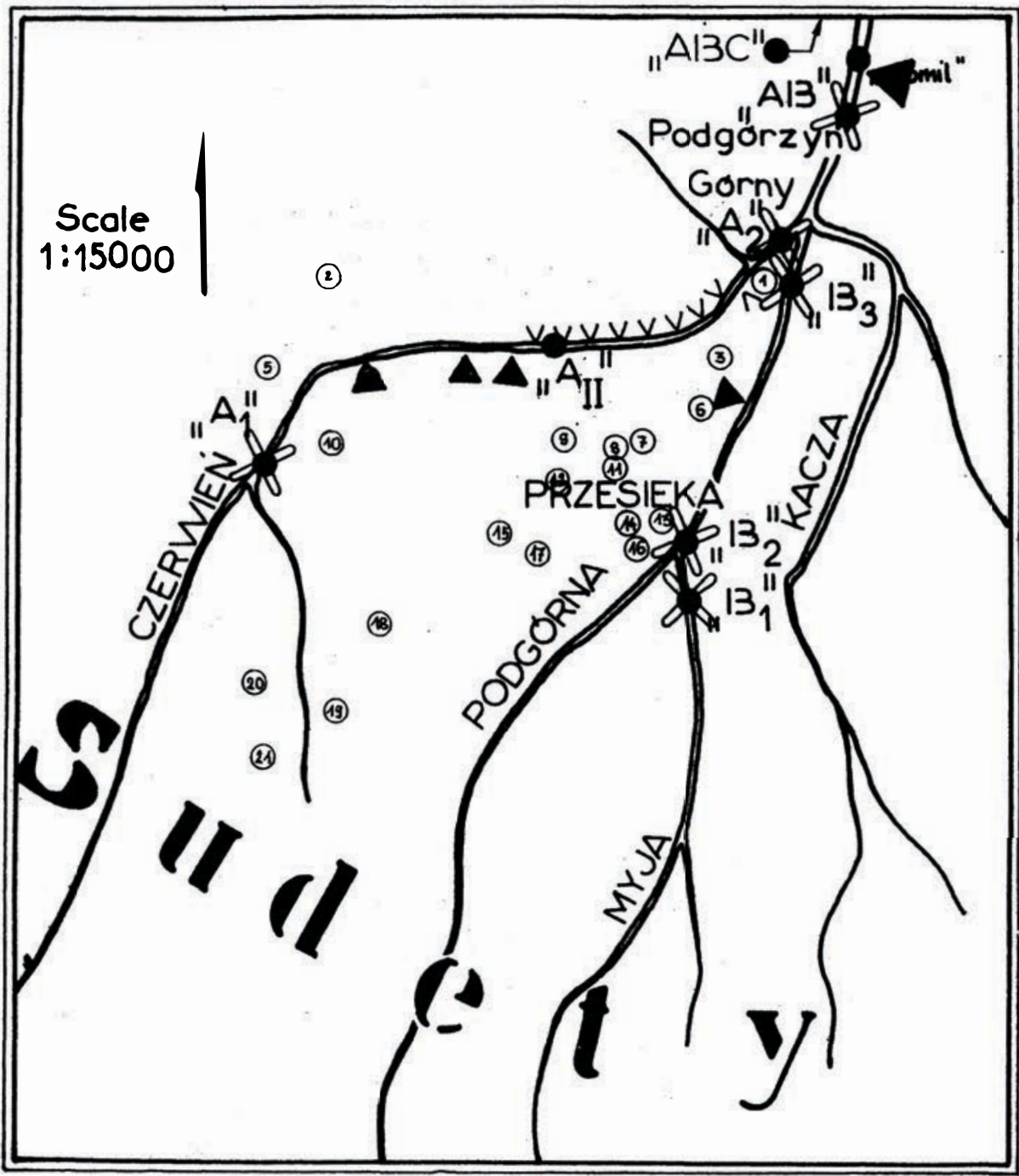

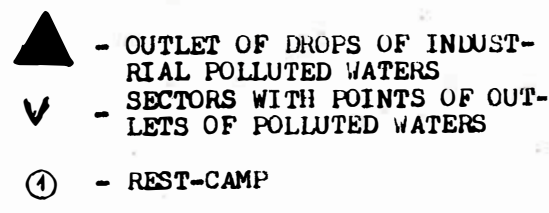

WATEKS

Fig. 1. Arrangement of profiles range of interests. nnc, test stands, localization of places of pollutions and rest-camps on the ground of Przesieka 
Assessment of the water quality is not easy thing because there is necessary doing a permanent confrontation of the results of biological and chemical analyses and finding out a close connection between these results.

Taking the thesis as described above under consideration and realizing the work at order of County Council of Jelenia Gora: "Inventory of pollution sources and hydrobiological examination of water quality of the basin of being built Sosnowka reservoir of drinking water for population of Jelenia Gora agglomeration", authors of this paper decided to reach their aim by means of routine as well as innovative research methods.

In the course of the realization above mentioned research there was found out that the acidification was a main agent which disqualified quality of water.

Having achieved the first authoritative results, authors aimed at increasing a low value of $\mathrm{pH}$ of water of the mountain streams by means of chalk addition. The attempt on deacidification was carried out under laboratory conditions. In the field, there were made efforts to show an advantageous impact of chalk on macro fauna.

\section{MATERIAL AND METHODS}

Materials presented in this paper were collected during the.field and the experimental works lasted from spring 1990 to winter 1990/91. The field experiments were

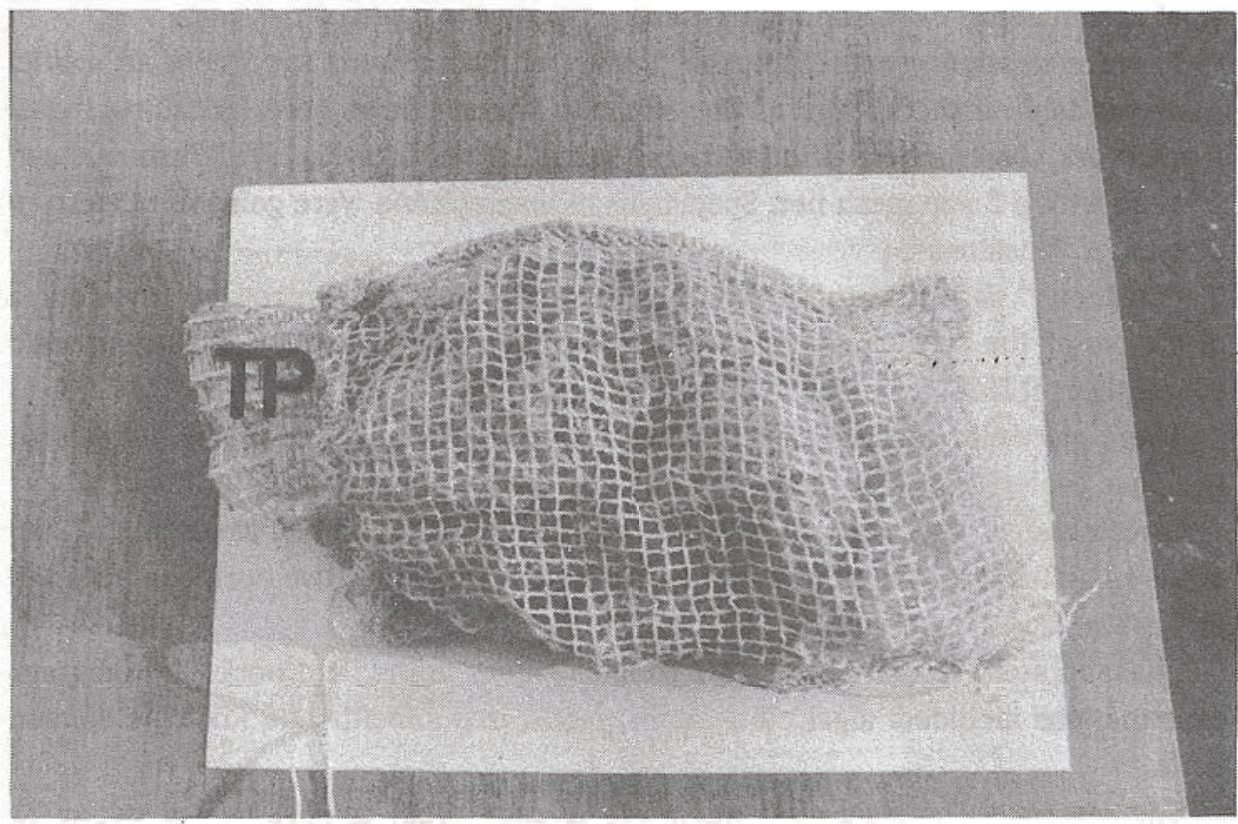

Fig. 2. Picture of "cushion" - openworked construction made with net, mesh $5 \times 5$ mm, filled with polypropylen texture (TP). Weight of cushion $=45.7 \mathrm{~g}$ 
included physical and chemical examinations of water, examinations of plankton and macrobenthos and interviews with inhabitants of the investigated area. On the basis of interviews the localization of outputs of waste waters were conducted and their intensity were estimated. The subject of this study were the streams nearby Przesieka mountain resort (Fig. 1).

Samples for the hydrochemical and biological examination were collected from surface of water in each test stand along the testing profiles with planktonic bucket.

Measurements of temperature, oxygenation (with $\mathrm{O}_{2}-$ meter $\mathrm{N}-5221$ ), pH (with $\mathrm{pH}-$ meter $\mathrm{N}-5123$ ) and ionic concentration of $\mathrm{Cl}^{-}, \mathrm{NO}_{3}^{-}, \mathrm{NO}_{2}^{-}, \mathrm{NH}_{4}^{+}, \mathrm{PO}_{4}^{3-}, \mathrm{SO}_{4}^{2+}, \mathrm{Al}^{3+}$ (testing sets of C.O.B.R. "Wzormat" which quality was confirmed by Polish Committee of Standardization of Measures and Qualities) were conducting. Moreover $\mathrm{BOD}_{5}$ and total hardness were determined by standard methods acc. to Hermanowicz et al. (1976). Examinations of plankton and benthos were carried out with the use of routine hydrobiological methods. The first of all the composition of species was examined. Quantity and biomass of macro fauna were-determined. Bioseston was filtered over mill gauze No. 25. Zoo benthos was sieved with a $1 \mathrm{~mm}$ mesh sediment sieve. Results of the chemical analyses were used for estimation of water pollution state of the streams (Fig. 1) by means of the index quality of water after A. Stojda, J. Dojlido, J. Woyciechowska (1985). On the basis od mentioned above hydrobiological analyses, saprobiotic indicators were determined. To the interpretation of the results of biological examinations Pantle and Buck method (1955) was applied.

In order to attain a representative number of macro fauna specimens an artificial base was laid on the bottom of the streams. The artificial base ("cushions") were a openwork constructions filled with polypropylen texture (Fig. 2). "Cushions" were covered with a $5 \mathrm{~mm}$ mesh net. Specimens of macro fauna were going over mesh into interior of "cushions".

"Cushions" as a substitute of natural base were easy colonized by invertebrates of bottom of the streams. Animals used "cushions" as protection against predators (Cover, Harrel 1978, Szlauer 1982).

There were two cushions left in each test stands to be colonized by animals with the same probability. "Cushions" were taking back from streams after about 21 days.

Invertebrates were washed out from "cushions" and examined according to stated above in methodic. In some test stands 4 cushions were left (two cushions with chalk and two ones without chalk).

The laboratory examinations were supplementary to the field work. The laboratory examinations included: algal cultivations, model experiments and toxilogic examinations.

The reason of the algal cultivation was to show what composition of micro flora species developed itself in water of averaged samples. The cultivation of algae was conducted in conical flashes $\left(\mathrm{V}=0.25 \mathrm{dm}^{3}\right)$ under just the same light conditions 
10 days. The model experiments were carried out in two glass basins filled with circulating water (D-experimental basin, K-controlling basin). Total volume of each basin was 50 liters. The circulation was forced and regulated by means of water-wheel. The base of basins was a rectangle shape with a barrier in the center that caused a circuitous movement of water (Fig. 3). There were made an efforts on maintaining of the same environmental conditions in the both basins. The only difference between these basis was the chalk on part of bottom of the experimental basin (D).

The model experiments were aimed at showing a possibility of increasing of $\mathrm{pH}$ of streams' water by means of enrichment of bottom structure with calcareous rocks (Wróbel, 1989). PH and oxygenation of circulating water was measured and analyzed.

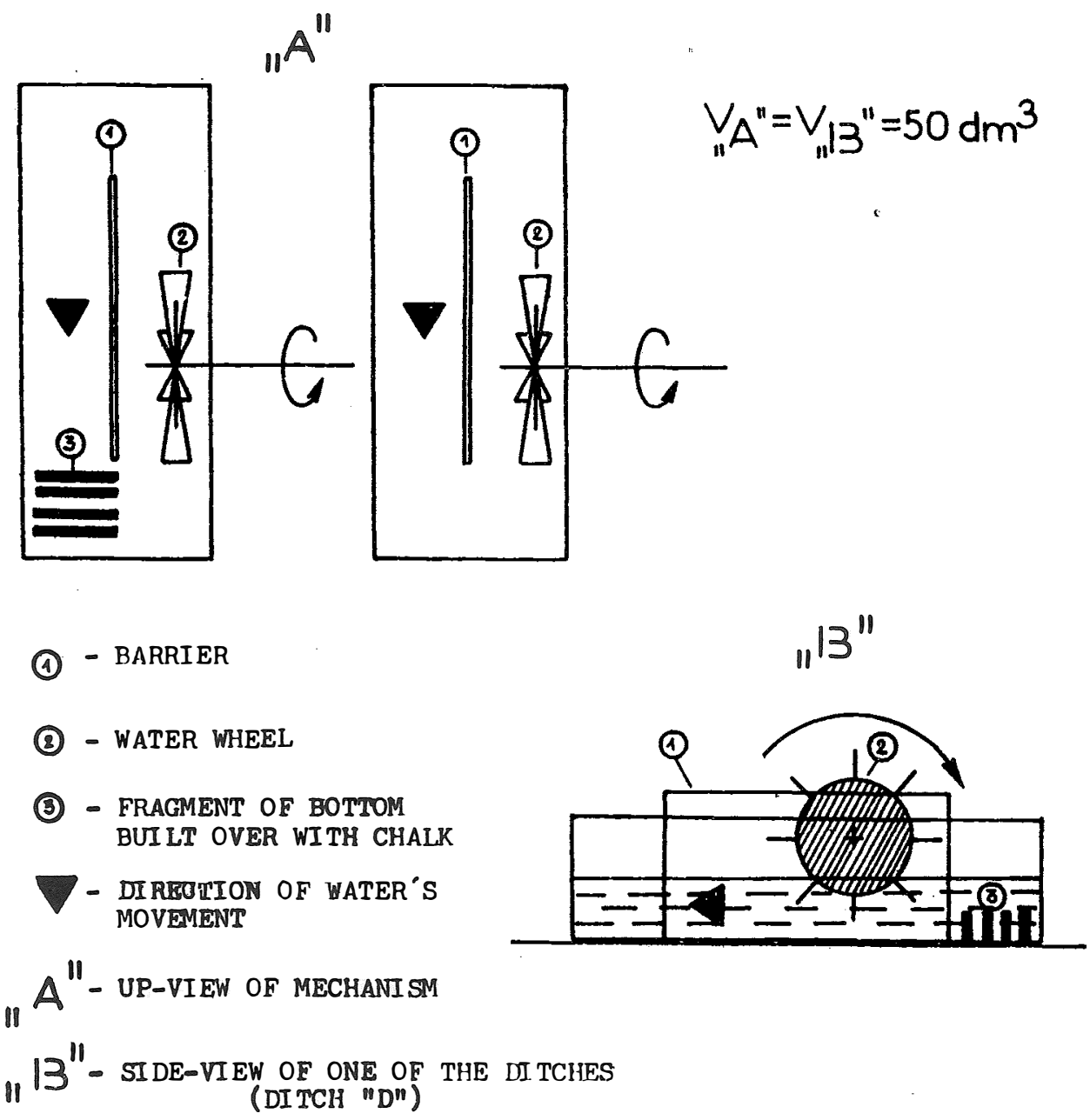

Fig. 3. Scheme of model mechanism 
Changes of physical and chemical factors of water taken from particular test stands (concentrations of ions given in $\mathrm{g} / \mathrm{m}^{3}$ )

\begin{tabular}{|c|c|c|c|c|c|c|c|c|c|c|c|c|c|}
\hline $\begin{array}{c}\text { Test } \\
\text { stand }\end{array}$ & Period * & $\mathrm{pH}$ & $\begin{array}{c}\text { Temp. } \\
\text { [C ] }\end{array}$ & $\begin{array}{l}\text { Oxygen } \\
{\left[\% \mathrm{O}_{2}\right]}\end{array}$ & $\mathrm{NO}_{3}$ & $\mathrm{NO}_{2}$ & $\mathrm{NH}_{4}$ & $\mathrm{PO}_{4}$ & $\mathrm{Cl}^{-}$ & $\mathrm{F}^{-}$ & $\begin{array}{c}\text { Total } \\
\text { hardness } \\
{[\mathrm{d}]}\end{array}$ & $\mathrm{SO}_{2}$ & $\mathrm{Al}^{3+}$ \\
\hline 1 & 2 & 3 & 4 & 5 & 6 & 7 & 8 & 9 & 10 & 11 & 12 & 13 & 14 \\
\hline \multirow{3}{*}{$B_{0}$} & $\begin{array}{l}\text { Spr } \\
\text { Sum } \\
\text { Atm }\end{array}$ & $\begin{array}{l}4.8 \\
4.7 \\
5.0\end{array}$ & $\begin{array}{r}5.0 \\
12.0 \\
8.5\end{array}$ & $\begin{array}{c}90 \\
95 \\
-\end{array}$ & $\begin{array}{c}20.0 \\
0 \\
0\end{array}$ & $\begin{array}{l}0 \\
0 \\
0\end{array}$ & $\begin{array}{l}0.2 \\
0.3 \\
0.1\end{array}$ & $\begin{array}{l}1.0 \\
1.0 \\
1.0\end{array}$ & $\begin{array}{l}3.0 \\
3.0 \\
3.0\end{array}$ & $\begin{array}{l}0 \\
0 \\
-\end{array}$ & $\begin{array}{l}1 \\
1 \\
1\end{array}$ & $\begin{array}{c}1.2 \\
1.2 \\
-\end{array}$ & $\begin{array}{c}10.0 \\
- \\
-\end{array}$ \\
\hline & WSY & 4.8 & 8.5 & - & 6.7 & 0 & 0.2 & 1.0 & 3.0 & - & 1 & - & $\dot{-}$ \\
\hline & MAN & $\begin{array}{l}4.1 \\
5.1 \\
\end{array}$ & $\begin{array}{r}4.5 \\
12.5 \\
\end{array}$ & $\begin{array}{r}80 \\
100 \\
\end{array}$ & $\begin{array}{c}0 \\
20.0\end{array}$ & $=$ & $\begin{array}{l}0 \\
0.4 \\
\end{array}$ & $=$ & $\begin{array}{l}2.0 \\
5.0 \\
\end{array}$ & $\bar{z}$ & $\begin{array}{l}1 \\
1\end{array}$ & $\bar{z}$ & $=$ \\
\hline \multirow{3}{*}{$B_{1}$} & $\begin{array}{l}\text { Spr. } \\
\text { Sum } \\
\text { Atm }\end{array}$ & $\begin{array}{l}5.1 \\
5.9 \\
5.4\end{array}$ & $\begin{array}{r}5.0 \\
11.0 \\
8.5\end{array}$ & $\begin{array}{r}92 \\
92 \\
100\end{array}$ & $\begin{array}{c}20.0 \\
0 \\
0\end{array}$ & $\begin{array}{l}0.02 \\
0.02 \\
-\end{array}$ & $\begin{array}{l}0 \\
0 \\
0.1\end{array}$ & $\begin{array}{l}3.0 \\
0.4 \\
0.6\end{array}$ & $\begin{array}{l}2.0 \\
3.0 \\
5.0\end{array}$ & $\begin{array}{l}0 \\
0 \\
-\end{array}$ & $\begin{array}{l}1 \\
1 \\
1\end{array}$ & $\begin{array}{c}1.2 \\
1.2 \\
-\end{array}$ & $\begin{array}{c}10.0 \\
- \\
-\end{array}$ \\
\hline & WSY & 5.5 & 8.2 & 95 & 6.7 & - & 0.03 & 1.3 & 3.3 & - & 1 & - & - \\
\hline & $\begin{array}{l}\text { MIN } \\
\text { MAX }\end{array}$ & $\begin{array}{l}5.0 \\
6.0\end{array}$ & $\begin{array}{r}5.0 \\
12.0\end{array}$ & $\begin{array}{r}89 \\
100\end{array}$ & $\begin{array}{c}0 \\
20.0\end{array}$ & $\begin{array}{l}0.01 \\
0.04\end{array}$ & $\begin{array}{l}0 \\
0.2\end{array}$ & $\begin{array}{l}0.2 \\
3.0\end{array}$ & $\begin{array}{l}1.5 \\
5.0\end{array}$ & - & - & - & - \\
\hline \multirow{3}{*}{$\mathrm{B}_{2}$} & $\begin{array}{l}\text { Spr } \\
\text { Sum. } \\
\text { Atm }\end{array}$ & $\begin{array}{l}4.5 \\
4.5 \\
4.7\end{array}$ & $\begin{array}{r}5.0 \\
11.5 \\
8.5\end{array}$ & $\begin{array}{r}96 \\
93 \\
100\end{array}$ & $\begin{array}{c}20.0 \\
0 \\
0\end{array}$ & $\begin{array}{l}0.02 \\
0 \\
-\end{array}$ & $\begin{array}{l}0.4 \\
0.2 \\
0.4\end{array}$ & $\begin{array}{l}2.0 \\
1.0 \\
0.4\end{array}$ & $\begin{array}{l}5.0 \\
3.0 \\
5.0\end{array}$ & $\begin{array}{l}0 \\
0.6 \\
-\end{array}$ & $\begin{array}{l}1 \\
1 \\
1\end{array}$ & $\begin{array}{l}1.2 \\
1.2 \\
1.2\end{array}$ & $\begin{array}{c}10.0 \\
- \\
-\end{array}$ \\
\hline & WSY & 4.6 & 8.3 & 96 & 6.7 & - & 0.3 & 1.1 & 4.3 & - & 1 & 1.2 & - \\
\hline & $\begin{array}{l}\text { MIN } \\
\text { MAX }\end{array}$ & $\begin{array}{l}4.5 \\
5.0\end{array}$ & $\begin{array}{r}5.0 \\
12.0\end{array}$ & $\begin{array}{r}91 \\
100\end{array}$ & $\begin{array}{c}0 \\
28.0\end{array}$ & $\begin{array}{l}0 \\
0.03\end{array}$ & $\begin{array}{l}0.1 \\
0.5\end{array}$ & $\begin{array}{l}0.2 \\
2.5\end{array}$ & $\begin{array}{l}2.0 \\
5.0\end{array}$ & $\overline{-}$ & - & - & - \\
\hline
\end{tabular}


continued tabl. 1

\begin{tabular}{|c|c|c|c|c|c|c|c|c|c|c|c|c|c|}
\hline 1 & 2 & 3 & 4 & 5 & 6 & 7 & 8 & 9 & 10 & 11 & 12 & 13 & 14 \\
\hline \multirow{3}{*}{$\mathrm{B}_{3}$} & $\begin{array}{l}\text { Spr } \\
\text { Sum } \\
\text { Atm }\end{array}$ & $\begin{array}{l}4.8 \\
5.3 \\
4.9\end{array}$ & $\begin{array}{r}9.0 \\
12.5 \\
8.0\end{array}$ & $\begin{array}{l}100 \\
100 \\
100\end{array}$ & $\begin{array}{l}20.0 \\
20.0 \\
20.0\end{array}$ & $\begin{array}{c}0.02 \\
0.04 \\
-\end{array}$ & $\begin{array}{l}0.4 \\
1.0 \\
1.0\end{array}$ & $\begin{array}{l}1.0 \\
1.0 \\
0.8\end{array}$ & $\begin{array}{r}15.0 \\
5.0 \\
5.0\end{array}$ & $\begin{array}{c}- \\
0.4 \\
-\end{array}$ & $\begin{array}{l}1 \\
1 \\
2\end{array}$ & $\begin{array}{l}1.2 \\
1.2 \\
1.2\end{array}$ & $\begin{array}{c}10.0 \\
- \\
-\end{array}$ \\
\hline & WSY & 5.0 & 9.8 & 100 & 20.0 & - & 0.8 & 0.9 & 6.7 & - & 1.33 & 1.2 & - \\
\hline & $\begin{array}{l}\text { MIN } \\
\text { MAX }\end{array}$ & $\begin{array}{l}4.8 \\
5.5\end{array}$ & $\begin{array}{r}8.0 \\
13.0\end{array}$ & 100 & $\begin{array}{r}5.0 \\
20.0\end{array}$ & $\begin{array}{l}0.01 \\
0.06\end{array}$ & $\begin{array}{l}0.1 \\
1.2\end{array}$ & $\begin{array}{l}0.5 \\
1.2\end{array}$ & $\begin{array}{r}5.0 \\
15.0\end{array}$ & - & $\begin{array}{l}1 \\
2\end{array}$ & $\overline{-}$ & $\overline{-}$ \\
\hline \multirow{3}{*}{$\begin{array}{l}\text { „STO- } \\
\text { MIL” }\end{array}$} & $\begin{array}{l}\text { Spr } \\
\text { Sum } \\
\text { Atm }\end{array}$ & $\begin{array}{l}4.9 \\
5.4 \\
5.6\end{array}$ & $\begin{array}{r}11.5 \\
13.0 \\
8.5\end{array}$ & $\begin{array}{l}90 \\
80 \\
-\end{array}$ & $\begin{array}{c}0 \\
10.0 \\
-\end{array}$ & $\begin{array}{c}0.02 \\
0.04 \\
-\end{array}$ & $\begin{array}{c}0.4 \\
0.4 \\
-\end{array}$ & $\begin{array}{l}- \\
0.5 \\
-\end{array}$ & $\begin{array}{r}50.0 \\
5.0 \\
-\end{array}$ & $\begin{array}{l}0 \\
0 \\
-\end{array}$ & $\begin{array}{l}- \\
1 \\
1\end{array}$ & $\begin{array}{l}1.2 \\
1.2\end{array}$ & $\begin{array}{c}10.0 \\
- \\
-\end{array}$ \\
\hline & WSY & 5.3 & 11.0 & - & - & - & - & - & - & - & - & - & - \\
\hline & $\begin{array}{l}\text { MIN } \\
\text { MAX }\end{array}$ & $\begin{array}{l}4.8 \\
6.0\end{array}$ & $\begin{array}{r}8.0 \\
13.5\end{array}$ & $\begin{array}{r}50 \\
100\end{array}$ & $\begin{array}{c}0 \\
20.0\end{array}$ & $\begin{array}{l}0 \\
0.08\end{array}$ & $\begin{array}{l}0 \\
0.4\end{array}$ & - & $\begin{array}{r}5.0 \\
50.0\end{array}$ & - & - & - & - \\
\hline \multirow{3}{*}{$A_{1}$} & $\begin{array}{l}\text { Spr } \\
\text { Sum } \\
\text { Atm }\end{array}$ & $\begin{array}{l}5.1 \\
5.1 \\
5.0\end{array}$ & $\begin{array}{r}5.0 \\
11.5 \\
7.5\end{array}$ & $\begin{array}{r}80 \\
100 \\
100\end{array}$ & $\begin{array}{c}10.0 \\
0 \\
0\end{array}$ & $\begin{array}{l}0 \\
0 \\
0.05\end{array}$ & $\begin{array}{l}0.3 \\
0.2 \\
0.4\end{array}$ & $\begin{array}{l}0.4 \\
0.2 \\
0.4\end{array}$ & $\begin{array}{l}5.0 \\
5.0 \\
5.0\end{array}$ & $\begin{array}{l}0 \\
0.4 \\
-\end{array}$ & $\begin{array}{l}1 \\
1 \\
1\end{array}$ & $\begin{array}{l}1.2 \\
1.2 \\
-\end{array}$ & $\begin{array}{c}10.0 \\
- \\
-\end{array}$ \\
\hline & WSY & 5.1 & 8.0 & 93 & 3.3 & 0.02 & 0.3 & 0.3 & 5.0 & - & 1 & - & - \\
\hline & $\begin{array}{l}\text { MIN } \\
\text { MAX }\end{array}$ & $\begin{array}{l}4.9 \\
5.5\end{array}$ & $\begin{array}{r}5.0 \\
12.0\end{array}$ & $\begin{array}{r}80 \\
100\end{array}$ & $\begin{array}{c}0 \\
10.0\end{array}$ & $\begin{array}{l}0 \\
0.05\end{array}$ & $\begin{array}{l}0.2 \\
0.4\end{array}$ & $\begin{array}{l}0.2 \\
0.6\end{array}$ & $\begin{array}{r}5.0 \\
10.0\end{array}$ & $\overline{-}$ & - & $\overline{-}$ & $\overline{-}$ \\
\hline \multirow{3}{*}{$\mathrm{A}_{2}$} & $\begin{array}{l}\text { Spr } \\
\text { Sum } \\
\text { Atm }\end{array}$ & $\begin{array}{l}5.3 \\
5.2 \\
6.2\end{array}$ & $\begin{array}{r}5.0 \\
12.5 \\
7.5\end{array}$ & $\begin{array}{r}80 \\
100 \\
100\end{array}$ & $\begin{array}{c}30.0 \\
0 \\
0\end{array}$ & $\begin{array}{l}0.02 \\
0.04 \\
0.05\end{array}$ & $\begin{array}{l}0.8 \\
1.0 \\
1.0\end{array}$ & $\begin{array}{l}0.3 \\
1.0 \\
0.3\end{array}$ & $\begin{array}{r}8.0 \\
10.0 \\
5.0\end{array}$ & $\begin{array}{l}0 \\
0.4 \\
-\end{array}$ & $\begin{array}{l}2 \\
2 \\
3\end{array}$ & $\begin{array}{l}1.2 \\
1.2 \\
-\end{array}$ & $\begin{array}{c}10.0 \\
- \\
-\end{array}$ \\
\hline & WSY & 5.6 & 8.3 & 93 & 10.0 & 0.04 & 0.9 & 0.5 & 7.6 & - & 2.33 & - & - \\
\hline & $\begin{array}{l}\text { MIN } \\
\text { MAX }\end{array}$ & $\begin{array}{l}5.0 \\
6.5\end{array}$ & $\begin{array}{r}4.5 \\
13.5\end{array}$ & $\begin{array}{r}80 \\
100\end{array}$ & $\begin{array}{c}0 \\
30.0\end{array}$ & $\begin{array}{l}0.02 \\
0.06\end{array}$ & $\begin{array}{l}0.2 \\
1.0\end{array}$ & $\begin{array}{l}0.2 \\
1.0\end{array}$ & $\begin{array}{r}5.0 \\
10.0\end{array}$ & $\overline{-}$ & $\begin{array}{l}2 \\
3\end{array}$ & $\overline{-}$ & $\overline{-}$ \\
\hline \multirow{3}{*}{$\mathrm{AB}$} & $\begin{array}{l}\text { Spr } \\
\text { Sum } \\
\text { Atm }\end{array}$ & $\begin{array}{l}5.0 \\
5.0 \\
4.8\end{array}$ & $\begin{array}{r}9.0 \\
12.0 \\
8.0\end{array}$ & $\begin{array}{r}97 \\
90 \\
100\end{array}$ & $\begin{array}{l}20.0 \\
20.0 \\
15.0\end{array}$ & $\begin{array}{l}0.02 \\
- \\
-\end{array}$ & $\begin{array}{l}0.4 \\
0.4 \\
0.4\end{array}$ & $\begin{array}{l}0 \\
1.0 \\
-\end{array}$ & $\begin{array}{l}30.0 \\
30.0 \\
35.0\end{array}$ & $\begin{array}{l}\overline{-} \\
-\end{array}$ & $\begin{array}{l}1 \\
1 \\
1\end{array}$ & $\begin{array}{l}1.2 \\
1.2 \\
1.2\end{array}$ & $\begin{array}{c}10.0 \\
- \\
-\end{array}$ \\
\hline & WSY & 4.9 & 9.7 & 96 & 18.3 & - & 0.4 & 0.3 & 31.2 & - & 1 & 1.2 & - \\
\hline & $\begin{array}{l}\text { MIN } \\
\text { MAX }\end{array}$ & $\begin{array}{l}4.7 \\
5.1\end{array}$ & $\begin{array}{r}7.5 \\
12.5\end{array}$ & $\begin{array}{r}90 \\
100\end{array}$ & $\begin{array}{l}10.0 \\
20.0\end{array}$ & $\bar{z}$ & $\begin{array}{l}0.2 \\
0.6\end{array}$ & $\begin{array}{l}0 \\
1.2\end{array}$ & $\begin{array}{l}30.0 \\
35.0\end{array}$ & $\overline{-}$ & $\overline{-}$ & $\overline{-}$ & $\overline{-}$ \\
\hline
\end{tabular}


The toxicologic examinations were conducted in ditches. A survival of selected hydrobionts were investigated. Respectives species of macro fauna were put in minilive boxes which were plunged into a circulating water. The toxicologic examinations were also conducted in others kind of vessels such as jars of $0.4 \mathrm{dm}^{3}$ volume.

10 of zoo benthos animals were introduced in the each jar. The experimental and controlling series of the toxicologic examination were conducted. Water for examination was taken from corresponding test stands. Animals were collected in the investigated streams and also in the Drawa river and Insko lake:

$\begin{array}{ll}\text { Hemiptera } & \text { - Aphelocheirus aestivalis (Fabr.) - imago } \\ \text { Odonata } & \text { - Calopteryx splendens Harr. (= Agrion splendens) - larvae } \\ \text { Plecoptera } & \text { - Perlodidae - larvae } \\ \text { Ephemeroptera } & \text { - Habroleptoides modesta (Hagen) - larvae } \\ \text { Trichoptera } & \text { - Hydropsyche lepida Pict. - larvae } \\ & - \text { Rhyacophila nubila Zetterstedt - larvae } \\ & - \text { Brachycentrus subnubilus Curt. - larvae } \\ \text { Amphipoda } & - \text { Pallasea quadrispinosa G.O. Sars. } \\ & - \text { Gammarus pulex Col. } \\ \text { Bivalvia } & - \text { Pisidium sp. Pfr. } \\ \text { Pisces } & - \text { Carassius auratus (L.) } \\ & - \text { Lebistes reticulatus Peters } \\ & - \text { Salmo gairdneri Richardson }\end{array}$

Some of the obtained results were checked by means of nonparametric test $(\alpha=0.05$ of significance level). The results statistical confirmed were specially accented in further part of this paper.

\section{RESULTS AND DISCUSSION}

Many factors such as temperature or soils of river basin, have their influence on water of the "Czerwien", "Myja" and "Podgórna" streams. Temperature of water depended on year season but there showed small fluctuations during period of the investigation (Table 1).

These studies were conducted in area of the ecological danger zone which is situated in the south-western part of Poland (Kassenberg, 1986) and close to "The Black Triangle" - (one of the most air polluted area in Europe).

Thus situation of studied area should be taken under consideration if an influence of soils of the basin Odra river on water of the streams is regarded. This influence was found out by authors of this paper and was showed in Table 1. Moreover a geological structure of the investigated area is advantageous for increasing of acidification. Analysis of the results showed in Table 1 seems to confirm the opinion described above 

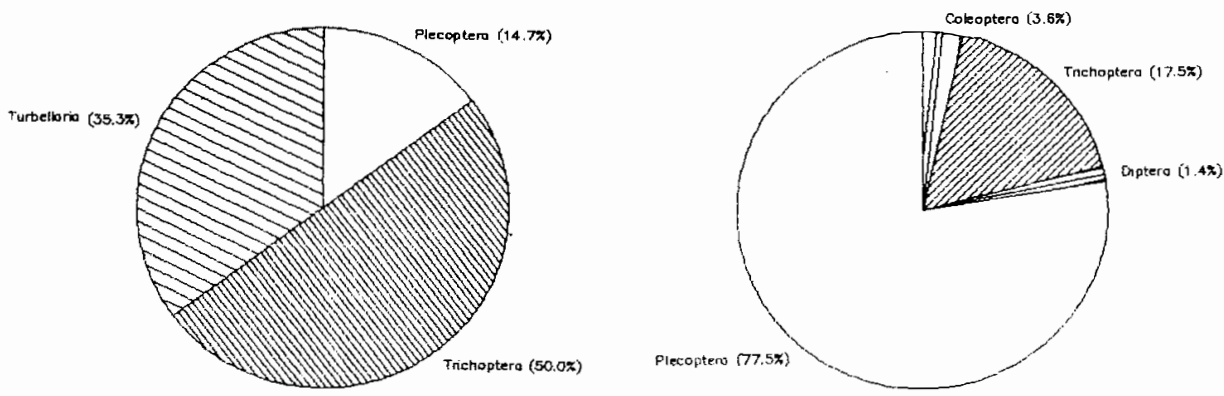

A.2

B.2
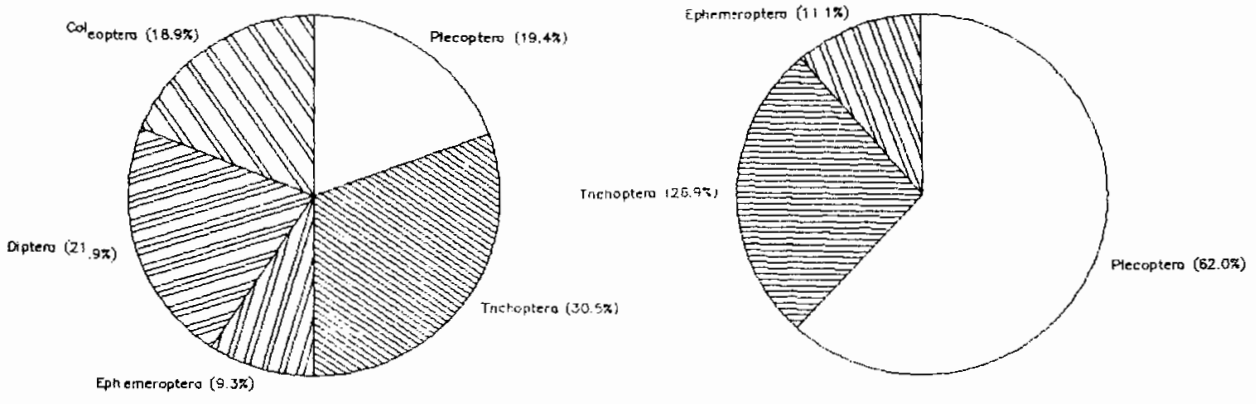

STOMIL
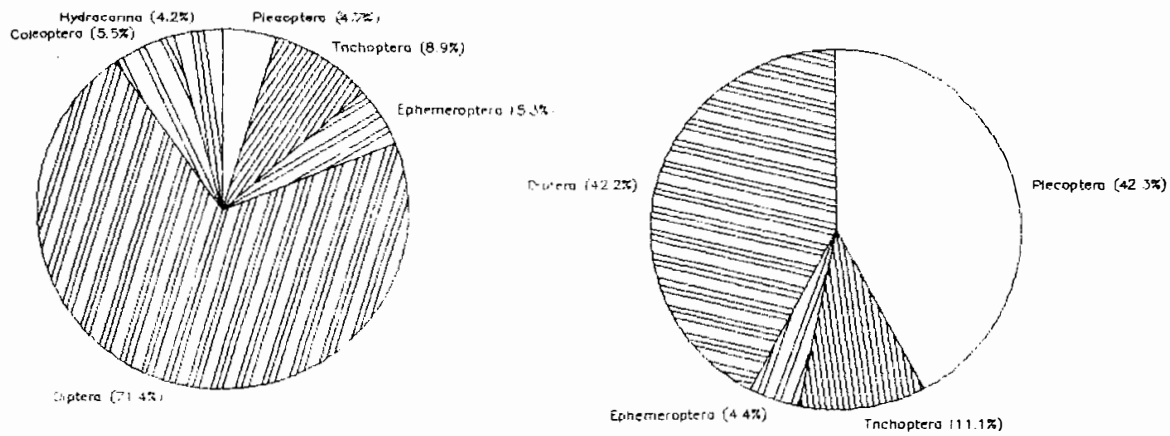

Fig. 4. Circle diagrams of proportional number of zoobentos taken (obtained) from cushions put in particular test stands 
Tuble 2

The plankton taken from myja, Czerwieñ and Podgórna streams from the particular test stands and from artificial culture of water of corresponding stands

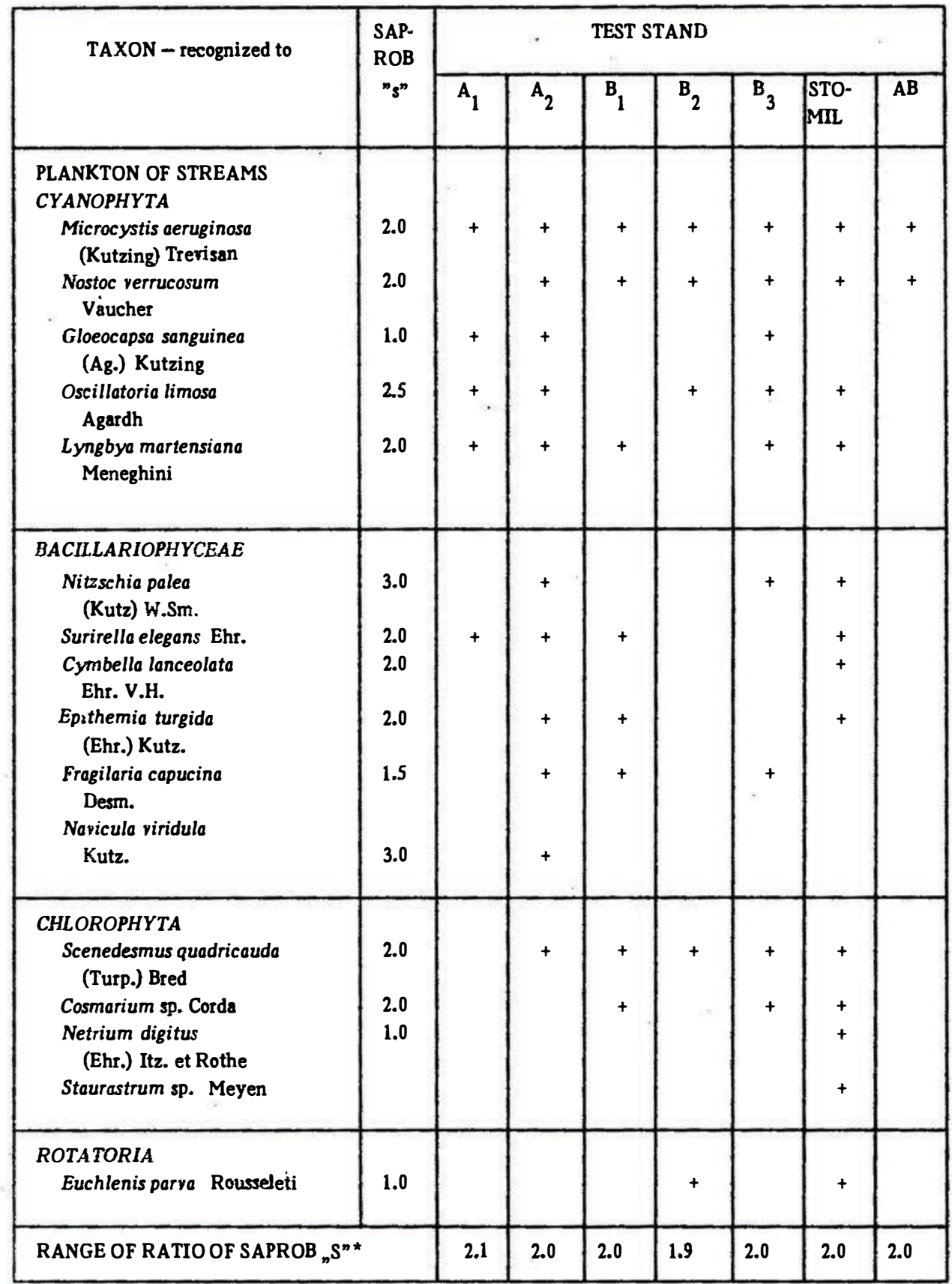


continued tab. 2

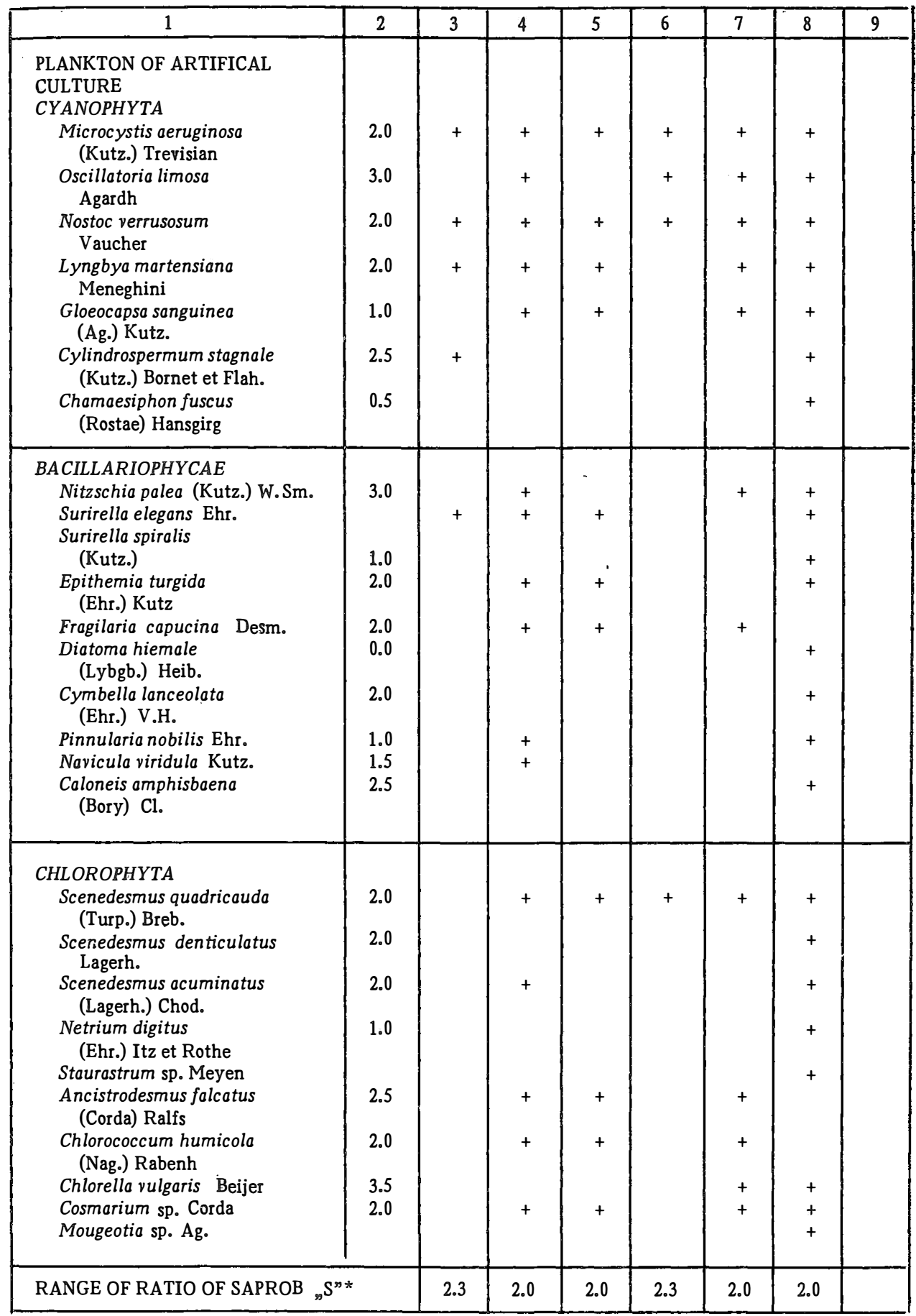

* according to Pantle and Buck 
The hamess of the investigated waters was very low (low calcium contents) and $\mathrm{pH}$ value was low (4.5 and lower). Such low pH value begins to create biological changes in er.vironment. Negative changes in environment are observed if acidification reaches $6.5 \mathrm{pH}$. Value of $5.6 \mathrm{pH}$ is a critical point of irreversible changes (Ecological Impact of Acid Precipitation, 1980).

The hydrobiological changes were caused by acidification of environment were shown in Table 2 and 3 . The biocenosis of the streams were not poor in species. However the predominant species belonged to Trichoptera and Plecoptera which occurred in the samples of each test stands* (Fig. 4) and affected trend of biomass of collected zoo benthos (Fig. 5). Results of acidification such as decrease of quantity of fish population (Sokofow and Winogradow, 1977) and decrease of precipitation of toxic carbonic acid $\mathrm{H}_{2} \mathrm{CO}_{3}$ in soft water of streams created advantageous conditions

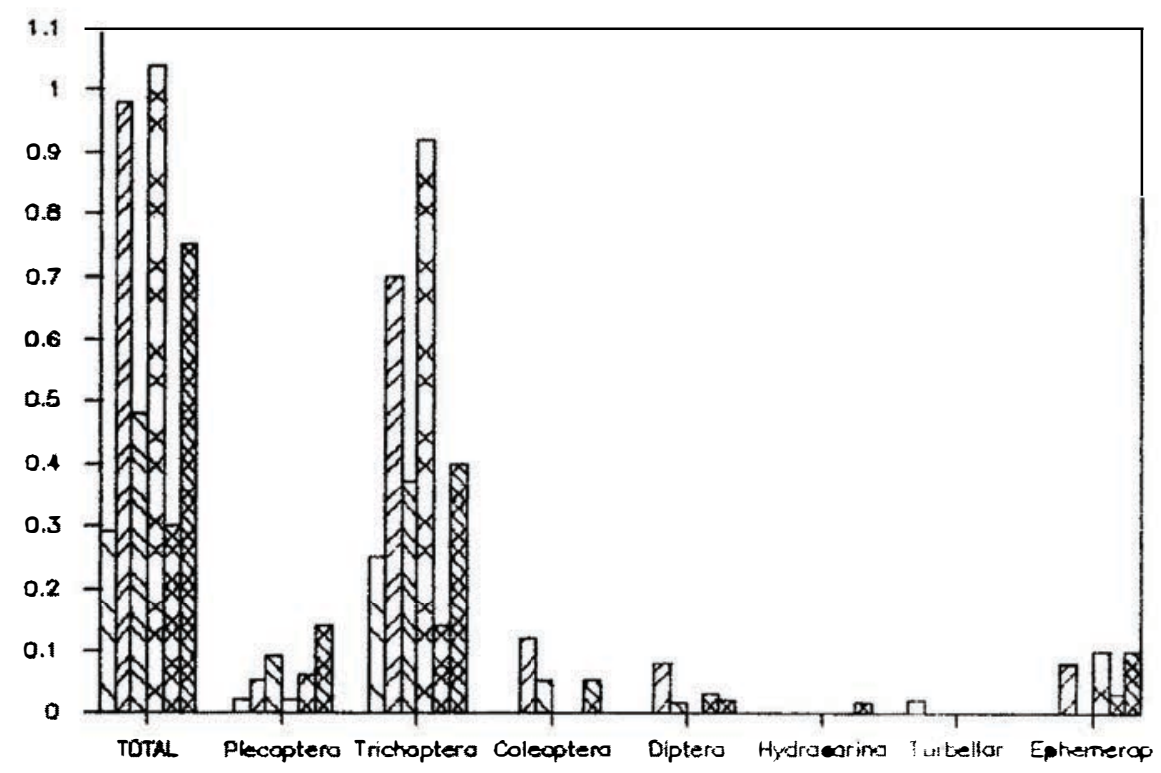

$\square$ teat stond A.1

ZCA test stand $A .2$

D8. Lest stond $\mathbf{B . 3}$

Stesi stand 81
test stord STOMIL.

Fig. 5. Biomass of bottom macro fauna settling the cushions put in particular test stands

"exposition time of "cushions" was relative short (5 days). 
The bentos taken from myja, Czerwień and Podgóna streams from the particular test stands

\begin{tabular}{|c|c|c|c|c|c|c|c|c|c|c|}
\hline \multirow{2}{*}{$\begin{array}{l}\text { TAXON } \\
\quad \text { - recognized to }\end{array}$} & \multirow{2}{*}{$\begin{array}{l}\text { Sap- } \\
\text { rob. } \\
\text { "s"* }\end{array}$} & \multicolumn{9}{|c|}{ Test stand } \\
\hline & & $\mathrm{A}_{1}$ & $\mathrm{~A}_{2}$ & $\mathrm{~B}_{0}$ & $B_{1}$ & $\mathrm{~B}_{2}$ & $B_{3}$ & $\begin{array}{l}\text { STO } \\
\text { MIL }\end{array}$ & $\mathrm{AB}$ & $\overline{\mathrm{ABC}}$ \\
\hline $\begin{array}{l}\text { ARACHNIDAE } \\
\text { Hydrachnellae } \\
\text { Sperchon sp. Kramer }\end{array}$ & & & & & & & & + & + & \\
\hline $\begin{array}{l}\text { EPHEMEROPTERA } \\
\text { Ameletus inopinatus Eaton } \\
\text { Siphlonurus aestivalis Eaton } \\
\text { Baetis sp. Leach }\end{array}$ & $\begin{array}{l}2.0 \\
1.0\end{array}$ & & $\begin{array}{l}+ \\
+\end{array}$ & & & + & & + & & \\
\hline $\begin{array}{l}\text { PLECOPTERA } \\
\text { Nemura sp. Latr. } \\
\text { Capnia nigra Pict. } \\
\text { Leuctra hippopus Kmpn. } \\
\text { Leuctra nigra (Oliv.) Kmpn. } \\
\text { Amphinemura sulcicollis Steph. } \\
\text { Perlodes sp. Banks. }\end{array}$ & $\begin{array}{l}0.0 \\
1.5 \\
1.0\end{array}$ & + & + & + & + & $\begin{array}{l}+ \\
+ \\
+\end{array}$ & $\begin{array}{l}+ \\
+ \\
+\end{array}$ & $\begin{array}{l}+ \\
+ \\
+\end{array}$ & $\begin{array}{l}+ \\
+ \\
+ \\
+\end{array}$ & $\begin{array}{l}+ \\
+ \\
+ \\
+\end{array}$ \\
\hline $\begin{array}{l}\text { COLEOPTERA } \\
\text { Donacia sp. Tbr. - larvae } \\
\text { Hydrobius sp. Leach - imago } \\
\text { Agabus undulatus Leach - imago } \\
\text { Coleoptera - imago }\end{array}$ & 1.5 & & $\begin{array}{l}+ \\
+ \\
+\end{array}$ & & $\dot{+}$ & & + & + & & \\
\hline $\begin{array}{l}\text { TRICHOPTERA } \\
\text { Chaetopteryx, sp. Steph. } \\
\text { Hydropsyche lepida Pict. } \\
\text { Polycentropus flavomaculatus Pict. } \\
\text { Anabolia nervosa Leach } \\
\text { Triaenodes bicolor Curt. } \\
\text { Grammotaulius sp. Fbr. } \\
\text { Rhyacophila nubila Zetterstedt } \\
\text { Glyphotoelius sp. Steph. } \\
\text { Notibodia cilaris L. } \\
\text { Silo sp. } \\
\text { Stenophylax sp. Colen. } \\
\text { Stenophylax stellatus Curt. } \\
\text { Leptocerus sp. Leach. }\end{array}$ & $\begin{array}{l}1.0 \\
2.0 \\
2.0 \\
1.5 \\
1.0 \\
1.0 \\
1.5 \\
\\
1.5 \\
1.0 \\
2.0\end{array}$ & $\begin{array}{l}+ \\
+\end{array}$ & $\begin{array}{l}+ \\
+ \\
+ \\
+\end{array}$ & + & $\begin{array}{l}+ \\
+ \\
+ \\
+\end{array}$ & $\begin{array}{l}+ \\
+ \\
+ \\
+ \\
+ \\
+ \\
+\end{array}$ & + & $\begin{array}{l}+ \\
+ \\
+\end{array}$ & $\begin{array}{l}+ \\
+ \\
+\end{array}$ & $\begin{array}{l}+ \\
+ \\
+ \\
+\end{array}$ \\
\hline $\begin{array}{l}\text { DIPTERA } \\
\text { Pericoma sp. } \\
\text { Dicranota sp. } \\
\text { Melusina sp. Meigen } \\
\text { Chironomus sp. Meigen } \\
\text { Chaoborus sp. Licht. } \\
\text { Pelopinae } \\
\text { Chironomidae }\end{array}$ & $\begin{array}{l}0.5 \\
4.0 \\
2.5\end{array}$ & & + & $\begin{array}{l}+ \\
+\end{array}$ & $\begin{array}{l}+ \\
+ \\
+\end{array}$ & + & $\begin{array}{l}+ \\
+ \\
+\end{array}$ & + & $\begin{array}{l}+ \\
+ \\
+ \\
+\end{array}$ & $\begin{array}{l}+ \\
+\end{array}$ \\
\hline TURBELLARIA & & + & & & & & & & & \\
\hline RANGE OF RATIO OF SAPROB. "S & & 1.5 & 219 & 275 & 142 & 163 & 125 & 103 & 173 & 142 \\
\hline
\end{tabular}

* according to Pantle and Buck. 
Compilation of values of unit indexes (VUIW) and total indexes of water's quality (IWQ) which were obtained on the basis of the results of analisis (the example for July 1990)

\begin{tabular}{|c|c|c|c|c|c|c|}
\hline \multirow{2}{*}{ Parameter } & \multicolumn{6}{|c|}{ Values of unit - index according to the test stands } \\
\hline & $B_{1}$ & $B_{2}$ & $B_{3}$ & $A_{1}$ & $A_{2}$ & $\mathbf{A} \mathbf{B}$ \\
\hline Temperature & 100 & 100 & 100 & 100 & 100 & 100 \\
\hline pH & 36 & 0 & 0 & 0 & 0 & 0 \\
\hline $\begin{array}{l}\text { Dissolved oxygen } \\
\mathrm{BOD}_{5}\end{array}$ & $\begin{array}{l}100 \\
68.7\end{array}$ & $\begin{array}{l}100 \\
68.7\end{array}$ & $\begin{array}{l}100 \\
29.4\end{array}$ & $\begin{array}{l}100 \\
68.7\end{array}$ & $\begin{array}{l}100 \\
29.4\end{array}$ & $\begin{array}{l}100 \\
73.7\end{array}$ \\
\hline Chlorides & 100 & 100 & 100 & 100 & 100 & 100 \\
\hline Sulphates " & 100 & 100 & 100 & 100 & 100 & 100 \\
\hline Amonia nitrogen & 100 & 92.7 & 78.7 & 92.7 & 78.7 & 87.1 \\
\hline Nitrates & 100 & 100 & 100 & 100 & 100 & 0 \\
\hline Ortophosphates & 57.8 & 25.0 & 25.0 & 32.5 & 25.0 & 25.0 \\
\hline $\begin{array}{l}\text { Total index of quality } \\
\text { of water (IWQ) }\end{array}$ & :66.76 & 0 & 0 & 0 & 0 & 0 \\
\hline
\end{tabular}

to Trichoptera and the Plecoptera to be predominant. There, was interesting that species of Ephemeroptera (a lethal pH - 5.4, Pantle and Buck, 1955) rare occurred in the samples. Ephemeroptera representatives were found in the samples only of 4 from among 9 test stands.

The interpretation of acidification of the streams as stated above, is not only but one of the most probable.

Tourism in the investigated area have an impact on quality of water of the streams. This influence is excellently shown in Fig. 1 and in Table 2, 3. These tables are almost ready interpretation ot the results by classification of water's quality in each of test stand.

There were a "practically" clean waters of the streams (oligo and $\beta$-mezosaprobic). Moreover a value of saprobic coefficient "S" depended on outlet of waste waters intensity and varied between 1.03 and 2.75 (Fig. 1). Compilation of values of unitary indexes water's quality (IWQ) were presented in Table 4. The unitary indexes water's quality were obtained by means of recalculating of the results presented in Table 1. Analysis of the values of IWQ clearly show an impact of outlet of waste waters intensity on quality of water of the streams. Following the current of the streams the values of IWQ were decreasing. Thus quality of water were decreasing too. 
Moreover, in the instance of two test stands ( $B_{3}$ and $A B-$ Table 4), IWQ obtained for $\mathrm{NO}_{3}^{-}$ions disqualified water as to be regarded as clean. The reason for such high $\mathrm{NO}_{3}^{-}$ions concentrations in such short length of the streams can be only outputs of waste waters.

Values of $\mathrm{pH}$ were the second agent which disqualified of water quality of the streams (in each test stands except $B_{1}$ ). Precise analysis of these described above results shows that abundance of species of macro benthos is higher in the samples taken from more polluted with waste waters test stands. This fact can be explained by a "saving" impact of waste waters. Waste waters increase $\mathrm{pH}$ value and on this basis they create an advantageous conditions for macro fauna of acidified streams. Moreover, waste waters are a source (direct and indirect) of food for animals and plants of the streams.

How short is this "saving" impact can be expressed by analysis of figures showed in Table 3. Samples collected in $A B$ and $A B C$ test stands were more poor in species compared with sample of "Stomil" test stand (Fig. 1. ABC test stand was situated above $A B$ test stand). $A$ better elucidation was proved in graph of mortality rate of Pallasea quadrispinosa (Fig. 6). Dynamics of dying of this crustacean was higher in $\mathrm{A}_{1}$ test stand than in $\mathrm{A}_{2}$ test stand but considerably lower compared with $\mathrm{AB}$ test stand.

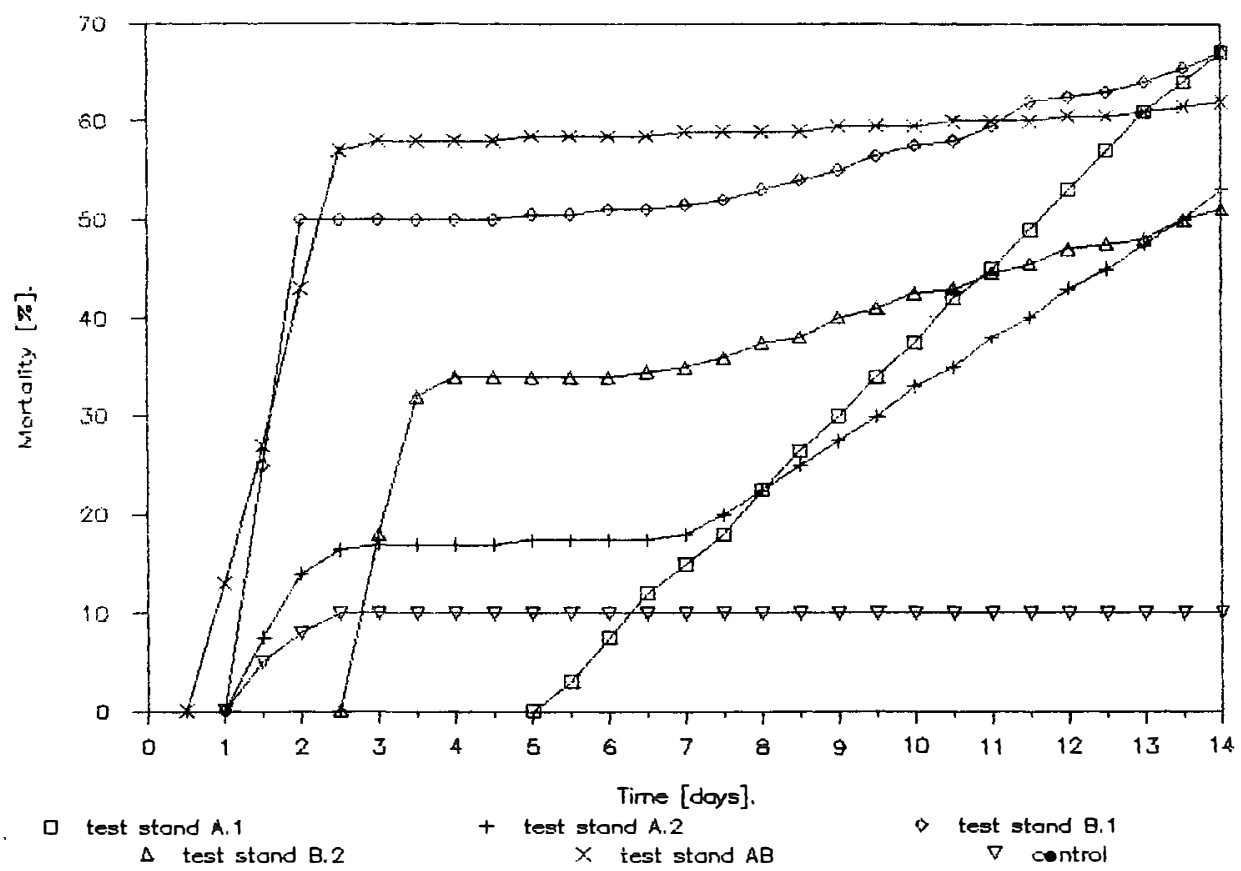

Fig. 6. Dynamics of dying Pallasea quadrispinosa in waters from particular test stands 


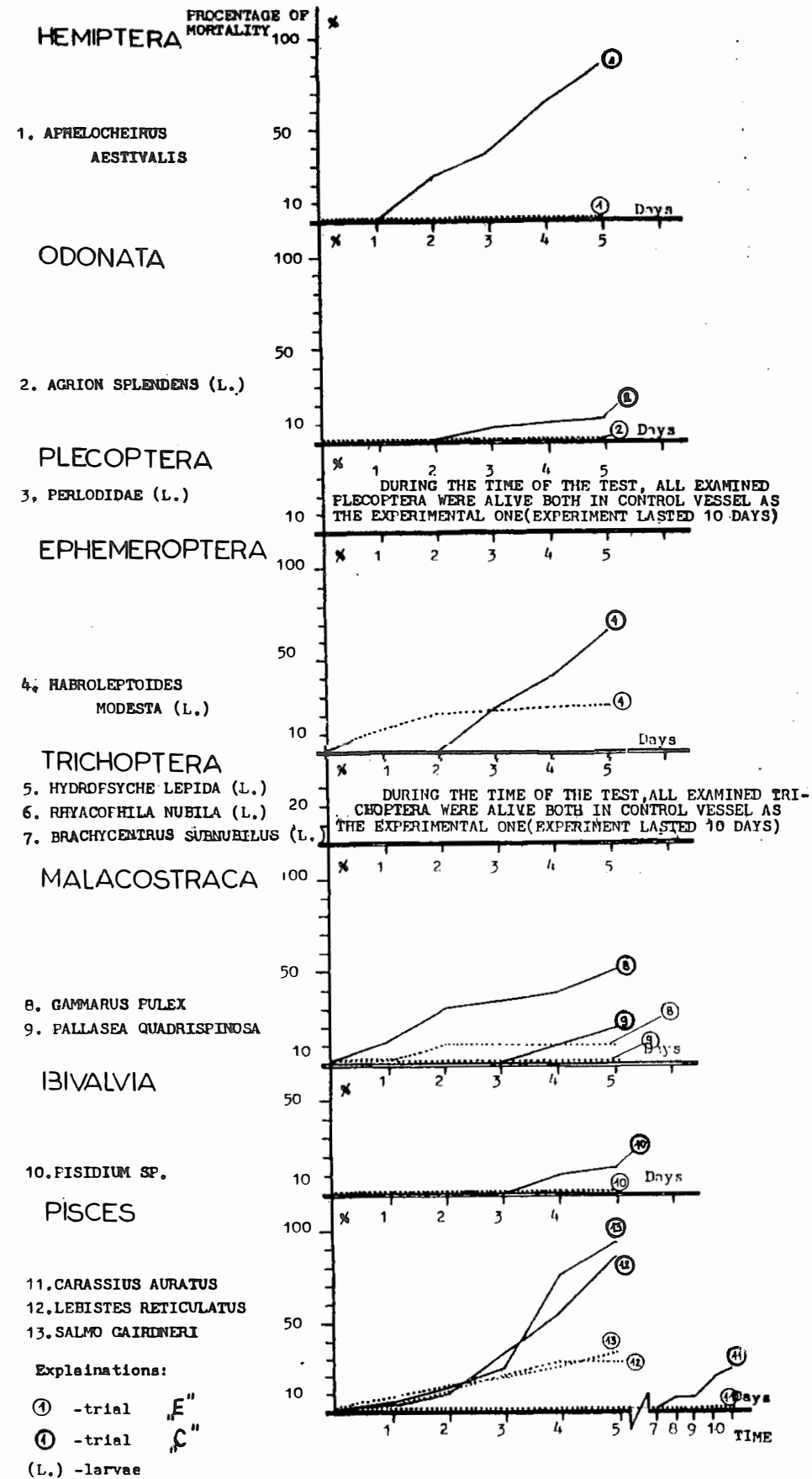

Fig. 7. Dynamics of dying of tested animals in model mechanism or in aquarium in the system: "C" - controlwater from stream Czerwien, " $E^{\prime}$ - experiment-water from stream Czerwien + chalk 
An attempt to find out a answer on question whether value of $\mathrm{pH}$ of water of the streams disqualified its quality was the second aim of this studies.

The model mechanism was used to examination of possibility of deacidification of water of the "Czerwien" stream with chalk. Value of $\mathrm{pH}$ of water taken repeatly from the streams with addition of chalk increased up to 7.6 (never over 8 ) although, two weeks circulation and surplus of chalk were applied. Consequently, the upper limit of the optimum range of $\mathrm{pH}$ values reported by Packer and Dunson, 1970; Schofield, 1976 and Sokołow and Winogradow, 1977 was not exceeded. Water in circulative basins was excellent oxygenated and had low temperature. Such as these parameters in the streams. A fulfilling above described conditions was necessary conducting an experiments with hydrobionts. Animals for these experiments were collected in the investigated streams and Drawa river.

A mortality were always lower for animals to be kept in circulative basins with chalk addition (Fig. 7). Similarly the mortality of others animals: crustacean - Pallasea quadrispinosa and fishes - Carassius auratus, Salmo gairdneri, Lebistes reticulatus that were tested in aquariums was lower for ones from vessels with chalk addition.

There should be accented that Salmo gairdneri is regarded as a sensitive on acidification (Acidification Today and Tomorrow, 1982). Moreover, a prospects of increas-

$$
\text { Autumn-Winter' } 90 / 91
$$

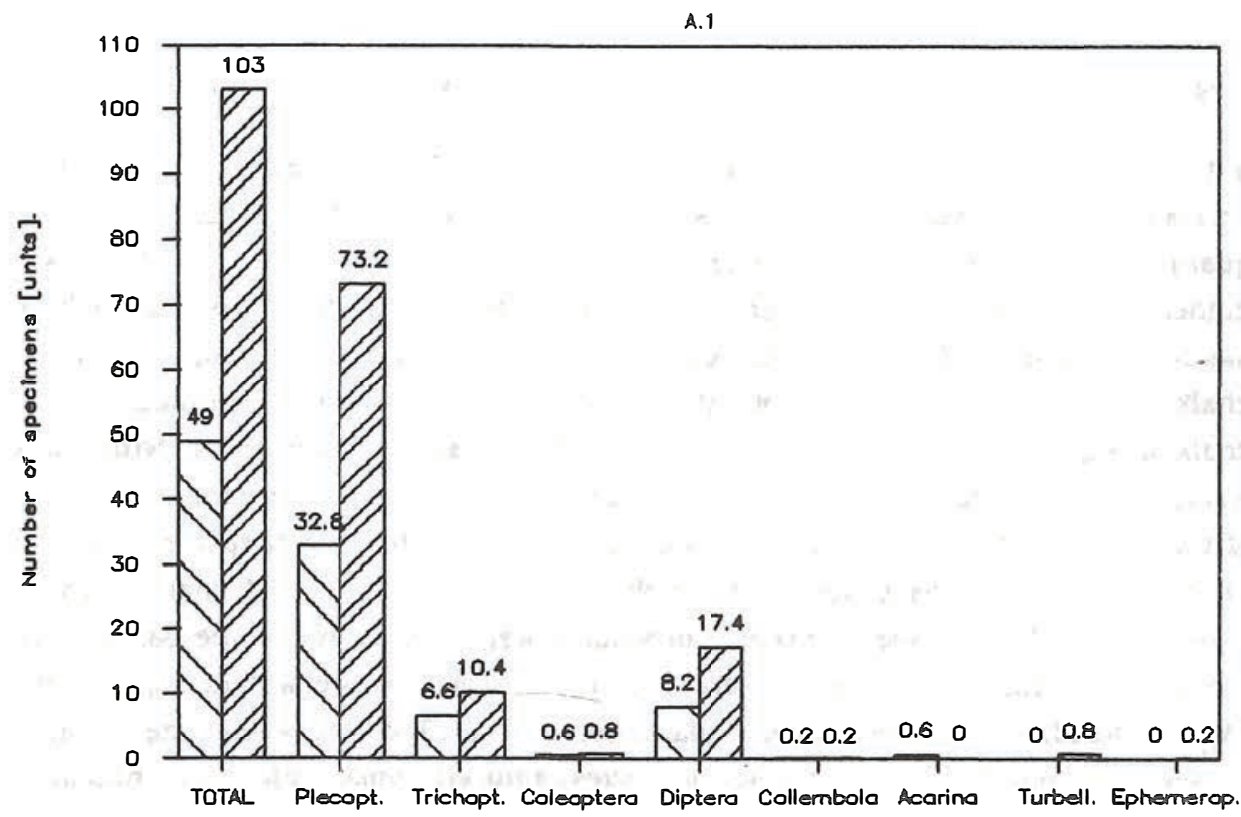

Cush.without chalk.

27 cushion with cholk.

Fig. 8. Average amount of organisms settling cushions (in two variants) at $A_{1}$ test stand in research period 


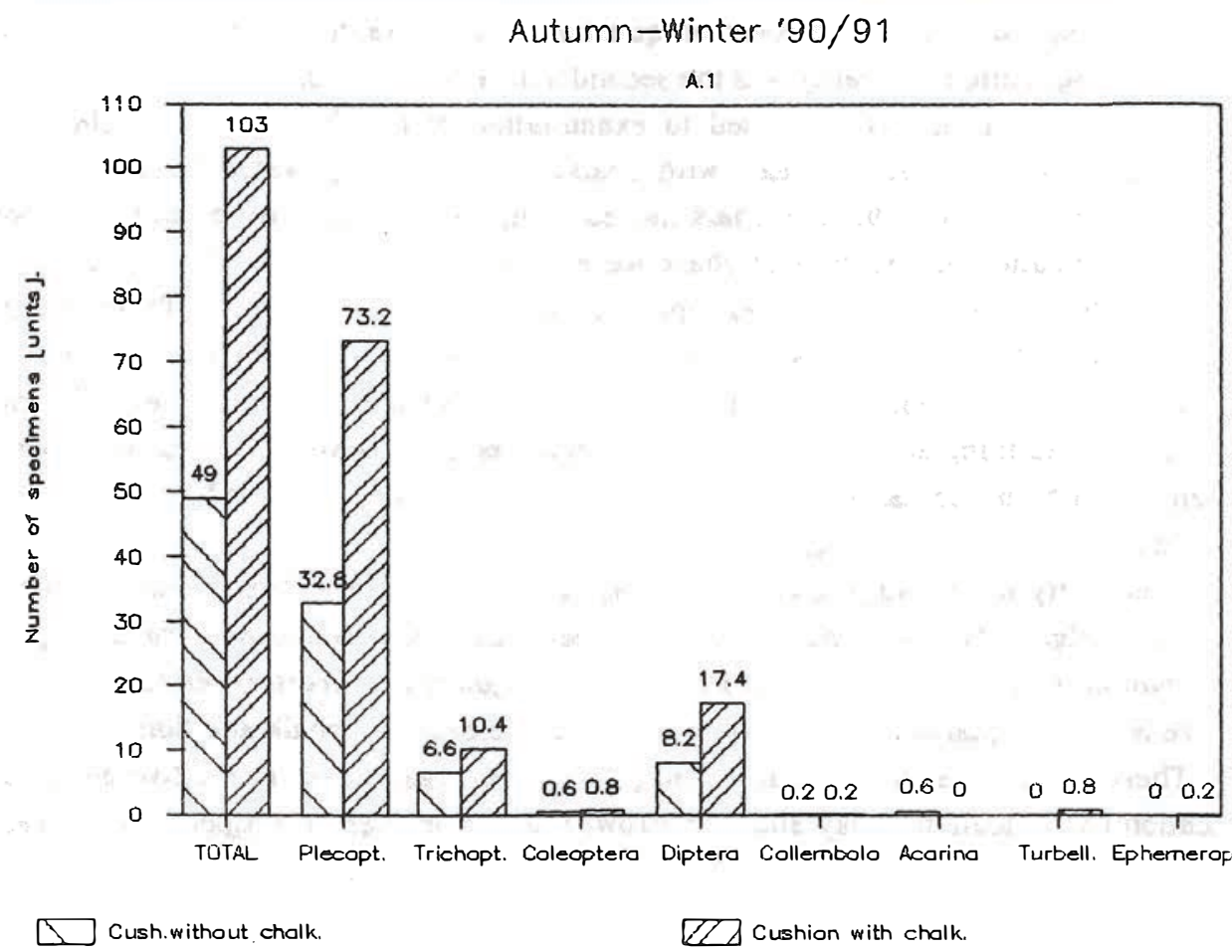

Fig. 9. Average amount of organisms settling cushions (in two variants) at $A_{\text {II }}$ test stand in research period

ing of $\mathrm{pH}$ value of the Czerwien stream in field situation were carried out (micro-scale). The authors put chalk into cushions (construction described in Methods). A new qualitatively environment was created in this way. The level of $\mathrm{pH}$ in cushions was higher than in surrounding water of the stream (even over two units). Animals of macro fauna gathered more in "cushions" with chalk addition $\left(A_{1}\right)$ than in ones without chalk (Fig. 8). The composition of gathered species in "cushions" with and without chalk was quantitatively and qualitatively different (Table 5). "Cushions" with chalk were, for example better colonized by different species of Trichoptera than by species of this Ordo in "cushions" without chalk. Moreover, constitution of species gathered in "cushions" with chalk was different than in "cushions" without chalk. Only in "cushions" with chalk specimens of Turbellaria were found. While the same "cushions" (with and without chalk) were put into stream in waste waters impact zone ( $A_{\text {II }}$ test stand) - there were not essential difference $(\alpha=0.05$ *) between the quantitatively and qualitatively constitution of species captured animals (Fig. 9). Significance

* significance level 
Table 5

Results of fishings by cushions exposed in the stream Czerwien at the $\mathrm{A}_{1}$ test stand

\begin{tabular}{|c|c|c|c|c|c|c|}
\hline \multirow{3}{*}{$\begin{array}{l}\text { TAXON } \\
\text { - recognized to }\end{array}$} & \multicolumn{6}{|c|}{ Average number of organism in cushion winter 1990/91 } \\
\hline & \multicolumn{2}{|c|}{ December } & \multicolumn{2}{|c|}{ January } & \multicolumn{2}{|c|}{ February } \\
\hline & C & E & C & E & C & E \\
\hline $\begin{array}{l}\text { PLECOPTERA } \\
\text { Nemuridae } \\
\text { Capnidae } \\
\text { Perlodidae }\end{array}$ & $\begin{array}{r}16 \\
31 \\
2\end{array}$ & $\begin{array}{r}33 \\
75 \\
0\end{array}$ & $\begin{array}{r}31 \\
16 \\
2\end{array}$ & $\begin{array}{r}31 \\
44 \\
0\end{array}$ & $\begin{array}{r}19 \\
14 \\
0\end{array}$ & $\begin{array}{r}24 \\
16 \\
1\end{array}$ \\
\hline $\begin{array}{l}\text { TRICHOPTERA } \\
\text { Polycentropus } \\
\text { flavomaculatus } \text { Pict. } \\
\text { Glyphotaelius. sp. Steph. } \\
\text { Limnophilus flavicornis } \text { L. } \\
\text { Notibodia ciliaris L. } \\
\text { Stenophylax } \text { sp. Colen. } \\
\text { Halesus tesselatus Steph. } \\
\text { Trichoptera }\end{array}$ & $\begin{array}{l}8 \\
8 \\
0 \\
0 \\
0 \\
0 \\
0 \\
0\end{array}$ & $\begin{array}{l}- \\
9 \\
4 \\
1 \\
0 \\
0 \\
0 \\
0\end{array}$ & $\begin{array}{l}5 \\
0 \\
0 \\
2 \\
0 \\
0 \\
0\end{array}$ & $\begin{array}{l}- \\
6 \\
0 \\
0 \\
0 \\
0 \\
0 \\
2\end{array}$ & $\begin{array}{l}0 \\
0 \\
0 \\
0 \\
1 \\
0 \\
0\end{array}$ & $\begin{array}{l}- \\
1 \\
1 \\
0 \\
0 \\
1 \\
2 \\
0\end{array}$ \\
\hline $\begin{array}{l}\text { COLEOPTERA } \\
\text { Platambus sp. Thomas - larvae } \\
\text { Agabus sp. Leach. - larvae } \\
\text { Hydroporus sp. Clrv. - imago }\end{array}$ & $\begin{array}{l}0 \\
0 \\
0\end{array}$ & $\begin{array}{l}1 \\
0 \\
0\end{array}$ & $\begin{array}{l}0 \\
0 \\
1\end{array}$ & $\begin{array}{l}0 \\
2 \\
0\end{array}$ & $\begin{array}{l}0 \\
0 \\
1\end{array}$ & $\begin{array}{l}0 \\
0 \\
0\end{array}$ \\
\hline $\begin{array}{l}\text { DIPTERA } \\
\text { Ablabesmyia sp. John. } \\
\text { Dicranota sp. } \\
\text { Pericoma sp. } \\
\text { Atherix sp. } \\
\text { Melusina sp. Meigen } \\
\text { Corynoneurinae } \\
\text { Tendipedinae }\end{array}$ & $\begin{array}{l}0 \\
3 \\
0 \\
1 \\
0 \\
3 \\
0\end{array}$ & $\begin{array}{r}7 \\
1 \\
1 \\
0 \\
0 \\
10 \\
0\end{array}$ & $\begin{array}{l}1 \\
5 \\
0 \\
0 \\
2 \\
2 \\
0\end{array}$ & $\begin{array}{r}6 \\
2 \\
0 \\
0 \\
0 \\
10 \\
1\end{array}$ & $\begin{array}{l}0 \\
0 \\
0 \\
0 \\
2 \\
0 \\
0\end{array}$ & $\begin{array}{l}1 \\
1 \\
0 \\
0 \\
1 \\
1 \\
0\end{array}$ \\
\hline COLLEMBOLA & 1 & 1 & 0 & 0 & 0 & 0 \\
\hline ACARINA & 1 & 0 & 0 & 0 & 0 & 0 \\
\hline TURBELLARIA & 0 & 0 & 0 & 1 & 0 & 1 \\
\hline TOTAL NUMBER OF SPECIMENS & 66 & 143 & 67 & 105 & 40 & 52 \\
\hline THE TOTAL BIOMASS $[\mathrm{g}]$ & 0.4518 & 0.4163 & 0.490 & 0.475 & 0.099 & 0.235 \\
\hline
\end{tabular}

C - cushion without chalk. E - cushion with chalk 
of difference for the results of $A_{1}$ and $A_{I I}$ test stands was obtained by means of nonparametric Wilcoxons test for 2 samples and $\alpha=0.05$. Thus chalk has the advantageous impact on macro fauna of the mountain streams.

\section{CONCLUSIONS}

1. The $\mathrm{pH}$ of water of streams the Czerwief, Myja, Podgorna is low and hydrobiological effects of acidification are observed there. Organisms of $\beta$-mezosaprobic zone live in these streams (Tab. 2 and 3).

2. Quality of outputs of waste waters has significant influence on water's quality of the investigated streams. Nevertheless their negative influence $(A B$ and $A B C$ test stands), waste waters increase low value of $\mathrm{pH}$ of water and are a food source for living organisms so far they are a reason of increasing of quantitatively and qualitatively abundance of macro fauna.

3. Negative influence of waste waters is limited by excellent oxygenation of the streams.

4. The results of research with circulative basins shows that there is possibility of reduction of acidification of the streams water by means of chalk.

5. There was not negative influence of chalk on macro fauna of the streams.

6. The bigger gathering of animals in "cushions" with chalk than in ones without chalk was found out and statistically confirmed.

7. There is a real chance creating conditions for reintroduction of trouts.*

\section{REFERENCES}

Acidification Todry and Tamaron, 1982: Swedish Ministry of Agriculture. - Environment 82 Committee. Core R.C., R.C. Harrel, 1978: Sequences of colonization, diversity biomas, and productivity of macroinvertebrates on artificial substrates in a freshwater canal. - Hydrobiologia, 59: 81-95.

Dojlido J., J. Woyciechowites, A. Stojda, 1983: Index water's quality. Gosp. Wod. nr 10.

Bcological Impect of Akid Prociptention, 1980: - Proc. Int. Conf. Sandfjord, Norway.

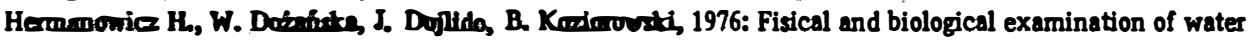
and waste waters. Arkady $\mathrm{W}$-wa.

Kancenber A, 1986: Regions of ecological danger - the new planning category. - Kosmos 1 (190): 154-160, PWN Warszawa.

Pecter R., W.A. Demson, 1970: Blood pH and Sodium Balance of Brock Trout. - J. Exp. Zool., vol. 174.

Pentile R., H. Buck, 1955: Die biologische uberwachtung die Gewasser und die Darstellung der Ergebnisse. Gasund Wasserfach, 96.

Schofiedd CI, 1976: Acid Precipitation: Effect on Fish. - Ambio, Vol. 5, No 5/6.

Setalon W.A., G.D. Whoogedon, 1977: Research on adaptation of fishes to various values of pH of environment. Biołogija wnutriennych wod. - Inform. Biull. AN SSSR. Wyp. 33.

\footnotetext{
- in many sections of the strears the oceurence of fishes are not observed (inhabitants of Przesieka - personel communication).
} 
Stamach Ko, S. Wro̊bel, K. Pasternak, 1978: Hydrobiology. - PWN, Warszawa.

Stojda A., J. Dojlido, J. Woyciechowska, 1985: Assessment of water quality by means of index water's quality. Gospodarka wodna, 12: 281-284.

Szlauer Lo, 1982: Assembling of water inverterbrates by means of artificial hiding - places in rivers. Prospects of using of this phenomenon. - Zeszyty Naukowe AR w Szczecinie, 93.

Wröbel S., 1989: Acidification of waters in Poland and attempt on their neutralization by means of dolomit. Materials of XIV Polish Hydrobiologists Congress: 225.

\section{Marek Świerczyński, Grzegorz Matlowski}

\section{PRÓBY NEUTRALIZACJI ZAKWASZONYCH WÓD GÓRSKICH NA PRZYKEADZIE BADANYCH POTOKÓW CZERWIEŃ, MYJA, PODGÓRNA}

\section{STRESZCZENIE}

Duża emisja $\mathrm{SO}_{2}$ i $\mathrm{NO}_{\mathrm{x}}$ w Polsce oraz ich kwaśne produkty powodują degradację środowiska. Degradacji tej podlegaję głównie wody na obszarach zbudowanych ze skał (krystalicznych, twardych) i produktów ich wietrzenia pozbawionych wapnia. Należą do nich m.in. potoki Karkonoszy. Dużym zakwaszeniem odznaczają się wody cieków: Podgórna, Myja, Czerwien - potoków badanych w aspekcie czystości wód zasilających nowo budowany zbiornik Sosnówka.

Stwierdzono, że wspomniane cieki mają wody o pH oscylującym w pobliżu wartości 5,0, a często ich odczyn spada poniżej 4,5. Niskie pH dyskwalifikuje wody potoków jako czyste pomimo pozytywnej oceny hydrobiologicznej (występują organizmy wód obligo- i $\beta$-mezosaprobowych). Skuttki zakwaszenia potoków są częsciowo niwelowane przez ścieki komunalne. $W$ celu wskazania tej zależności podjęto:

1. Biotestową ocenę zanieczyszczenia wód (w tym ich zakwaszenia), przez wykorzystanie zjawiska osiedlania się organizmów na sztucznym podłożu - „poduszkach”.

2. Badania modelowe nad neutralizacją zakwaszonej wody potoków za pomocą kredy. Doświadczenia prowadzono w urządzeniu mającym postać dwóch basenów cyrkulacyjnych i w potoku Czerwień, w którym stworzono enklawy zobojętnionego środowiska (z zastosowaniem „poduszek").

Badania potwierdziły powyższą zależnošć i korzystne oddziaływanie kredy na odczyn wód potoków oraz na ich makrofaunę i szereg testowanych organizmów.

Authors' address:

Received: 1991.04 .25

Mgr Marek Świerczyñski, Mgr Grzegorz Matławski

Wydział Biologii i Nauk o Morzu

Katedra Ekologii Zwierząt

ul. Felczaka 3a

71-412 Szczecin

Polska (Poland) 